\title{
Association of ACE I/D Gene Polymorphism and Related Risk Factors in Impaired Fasting Glucose and Type 2 Diabetes: A Study Among Two Tribal Populations of North-East India.
}

\author{
SUNANDA RAJKUMARI \\ University of Delhi Department of Anthropology \\ SOMORJIT SINGH NINGOMBAM \\ AlIMS: All India Institute of Medical Sciences \\ VARHLUN CHHUNGI \\ ICMR-National Institute of Malaria Research: National Institute of Malaria Research \\ MASAN KAMBO NEWMEI \\ University of Delhi Department of Anthropology \\ NAOREM KIRANMALA DEVI \\ University of Delhi Department of Anthropology \\ PRAKASH RANJAN MONDAL \\ University of Delhi Department of Anthropology \\ Kallur Nava Saraswathy ( $\sim$ knsaraswathy@yahoo.com ) \\ University of Delhi Department of Anthropology
}

\section{Research Article}

Keywords: Impaired fasting glucose, Type 2 diabetes, ACE I/D polymorphism, Dyslipidemia, GenexEnvironment interaction, Tribal population

Posted Date: September 2nd, 2021

DOI: https://doi.org/10.21203/rs.3.rs-844758/v1

License: (c) (i) This work is licensed under a Creative Commons Attribution 4.0 International License. Read Full License

Version of Record: A version of this preprint was published at Molecular Biology Reports on November 10th, 2021. See the published version at https://doi.org/10.1007/s11033-021-06924-7. 


\section{Abstract}

AIM

Type 2 diabetes is a serious public health concern in India, even the indigenous tribal populations are not felt unaffected. The present study aims to understand the association of major risk factors i.e obesity, hypertension, dyslipidemia, ACE I/D polymorphism with impaired (IFG) and type 2 diabetes (T2D) among two different Mendelian populations of North East India.

METHOD

Demographic, somatometric and physiological variables along with fasting blood samples were collected from 609 individuals. ACE I/D polymorphism was screened.

RESULT

ACE I/D polymorphism was found to follow HWE among Liangmai tribe but not among Mizo tribe. Distribution of DD genotype/D allele was found to be significantly higher for T2D among Mizo (OR 2.10; 95\% Cl 1.10-4.39, OR 2.10;1.16-4.09 respectively ).Significant association between DD genotype/D allele of ACE I/D polymorphism and TC in both IFG (OR 2.22; 95\% Cl 1.14-4.32) and T2D (OR 2.53;95\% Cl 1.51-4.23) were observed. LDL was also found to posed significant risk for IFG (OR 2.10;95\% $\mathrm{Cl} 1.10-3.91)$ and T2D (OR 1.04; 95\% $\mathrm{Cl} 1.02-1.06)$.

\section{CONCLUSION}

The present study is an example of gene-environment interaction where DD genotype or D allele and dyslipidemia (high TC and high LDL) are posing risk for IFG and T2D both independently and in combination only among Mizo tribe with relatively less physical activity attributed to their residence in less hilly terrain, but Liangmai tribe which resides in high hilly terrain shows no such association.

\section{Introduction}

Type 2 diabetes is a serious public health problem, affecting both developed and developing countries [1-3]. Type 2 diabetes was commonly regarded as a disease of affluent societies previously but now it encroached among the rural and urban [4], irrespective of their ethnicity, class and socio-economic condition. Even the indigenous tribal populations of India which are undergoing epidemiological transition are affected by diabetes with prevalence ranging up to $10 \%$ and further increasing, with a final estimate of $5.9 \%[5,6]$.

Diabetes increases the risks for cardiovascular and metabolic diseases thereby reducing the quality of life and increasing the risks for premature mortality [7]. The increasing prevalence of Type 2 diabetes is contributed by increasing trend of obesity, hypertension, physical inactivity and studies have also shown the association of Type 2 diabetes with dyslipidaemia [8]. Diabetes is multifactorial in origin with both environmental and genetic factors contributing to its pathogenesis [9]. The gene encoding angiotensin converting enzyme has listed as one of the widely evaluated candidate gene in association with Type 2 diabetes. The angiotensin converting enzyme (ACE) is a key component of renin-angiotensin system (RAS) by generating vasoconstrictor angiotensin II and degrading kinins [10]. High levels of angiotensin II have been suggested to play an important role in glucose and insulin regulation which may increase the risk of insulin resistance and diabetes [11]. Angiotension converting enzyme located on chromosome 17q23, has many polymorphisms, of which 287base pair Alu insertion/deletion (I/D) polymorphism in intron [12]. The DD genotype is associated with higher levels of circulating ACE than ID and II genotype, in previous reports D allele of ACE I/D polymorphism are associate with many cardiovascular diseases [13,14], such as Type 2 diabetes [15,16] metabolic syndrome [17], hypertension [18,19], central obesity [20] and hypertriglyceridemia [21]. The present study attempts to understand the association of major risk factors i.e obesity, hypertension, dyslipidemia, ACE I/D polymorphism with impaired fasting glucose (IFG) and Type 2 diabetes (T2D) among two different Mendelian populations, with different gene pools. The two selected tribal populations have been reported to have different ancestral origins [22,23], different lifestyle and inhabit different ecological niche. The Liangmai Naga tribe inhabit the villages of high hilly terrain of Tamenglong and Senapati districts while Mizo tribe inhabit the low-lying hilly terrain villages of Churachandpur districts of Manipur. The two selected study populations are reported to be different with respect to the distribution of obesity where obesity among Mizo tribe was higher as compared to that of the Liangmai population [24]. The prevalence of IFG and T2D were also reported to be significantly higher among Mizo tribe as compared to Liangmai tribe [25].

\section{Methodology}

2.1 Study design and data collection 
The details of the study design, recruitments of the study participants, collection and categorization of data pertaining to demographic, somatometric measurements, fasting blood glucose levels [26] and blood pressure and lipids variables [27] have been mention in our previous studies. Categorization of blood pressure has been done by JNC 7 guidelines [28] and lipids by NCEP ATP III guidelines [8]. In the present study, ACE I/D polymorphism was successfully genotyped for 611 individuals (339 Liangmai, 269 Mizo).

\subsection{PCR and genotyping of ACE I/D polymorphism}

Extraction of DNA was done by using salting-out method [29]. Genotyping of ACE I/D gene polymorphism was carried out using Forward primer sequence: 5'CTG GAG ACC ACT CCC ATC CTT TCT 3'and reverse primer sequence: 5' GAT GTG GCC ATC ACA TCC GTC AGAT 3' [30] .The PCR was carried out using the Thermocycler (C-1000 Touch ${ }^{\mathrm{TM}}$, Bio-Rad, USA). Genotyping of PCR products [in base pair(bp), DD (190bp), ID (490bp,190bp) and II (490bp)].

\subsection{Statistical analysis}

Variation in the distribution of allele and genotype within the population was done by using Hardy-Weinberg Equilibrium. Chi square test was used to see the differences in the distribution of the genotype and the categorical variables. Logistic regression analysis was used to determine risk after adjustment with confounders. All analyses were performed using the Statistical Package for the Social Sciences (SPSS, for Windows version 20.0). Statistical significance was taken at $p$ value $\leq 0.05$ for all the statistical tests.

\section{Results}

As per the previous report by [24] on the same cohort, percentage of individuals with higher age was significantly higher among the Type 2 diabetes group as compared to their respective controls among both Liangmei and Mizo groups. No such difference was observed between the IFG cases and their respective controls in both the studied population groups.

The two populations were found to be significantly differing with respect to the distribution of ACE I/D rs4646994 polymorphism where individuals with DD genotype were found to be significantly higher among the Mizo tribe. ACE I/D rs4646994 polymorphism was found to follow hardy-weimberg equlibrium (HWE) among the Liangmai tribe, but not in Mizo tribe. However, D allele frequency is higher among the Liangmai tribe i.e. D-0.52 as compared to that of the Mizo tribe i.e. D-0.4. The distribution of ACE I/D rs4646994 polymorphism as per fasting blood glucose levels i.e normoglycemia, impaired fasting glucose (IFG) and type 2 diabetes (T2D) among Liangmai and Mizo populations of Manipur indicate no significant differences between the case and control groups in Liangmai tribe. Whereas in Mizo tribe DD carrying individuals are found to be higher in percentage among the Type 2 diabetes group as compared to their respective controls with a suggestive p-value (Table 1).

Odds ratio analysis after controlling the age reveals more than 2 -fold significant increased risk of DD genotype / D allele (OR $2.10,95 \% \mathrm{Cl}$ 1.10-4.39, OR 2.10,1.16-4.09 respectively) for T2D only among Mizo tribe and not among Liangmai tribe (Table 2).

Distribution of individuals with abnormal lipids which includes total cholesterol (TC), triglycerides (TG), low-density lipoprotein (LDL), highdensity lipoprotein (HDL), very low-density lipoprotein (VLDL) among cases (i.e. IFG and T2D) and their respective controls (normoglycemia) shows that individuals with high total cholesterol (TC) and high low-density lipoprotein (LDL) are found to be significantly higher among both the cases i.e. IFG and T2D as compared to that of their respective controls only in Mizo tribe. Whereas no such differences were observed between cases and control with respect to the distribution of dyslipidemia among Liangmai tribe. [Figure 1(a), 1(b)]. No differences were observed in the distribution of obesity among the case and their respective controls in both the population [24]. Odds ratio analysis of obesity, hypertension, and lipids variable also reveals more than 2-fold significant increased risk for TC in both IFG (OR 2.22, 95\% Cl 1.144.32) and T2D (OR 2.53,95\% Cl 1.51-4.23) in Mizo tribe. LDL also posed 2-fold significant increased risk for IFG (OR 2.10,95\% Cl 1.10-3.91) and 1-fold increased risk for T2D (OR 1.04, 95\% Cl 1.02-1.06) in Mizo tribe [Figure 2(b), 2(d)]. Odds ratio analysis between lipids and ACE I/D polymorphism show no association between the two in both Liangmai and Mizo tribe (Supplementary Table 1).

GenexEnvironment interactions analysis (Table 3) shows more than 2-fold significant increased risk for both IFG and Type 2 Diabetes when there is a combination of D allele with high TC and high LDL only among the Mizo tribe and not among the Liangmai tribe.

\section{Discussion}

Studies associating ACE ID polymorphism with either IFG and type 2 Diabetes show variable results, where some show positive association [10-12,14-16,31,32],14,15,16,31] and some no association [33-35,40] and some negative association [36,37,41]. These discrepancies in the association are usually attributed to the limitation of differing ethnicities and study designs [42]. To overcome the 
limitation, in the present study, both case and controls are derived from the two Mendelian populations and the association analysis was done in both the population groups separately. The 2 studied Mendelian populations not only have different gene pools because of relatively restricted mating rules within the population and they also inhabit different ecological niche i.e Liangmai tribe inhabit relatively higher hilly terrain and Mizo tribe inhabit a lower altitude hilly terrain. These differences in the genetic and environmental background must have led to the differential distribution of complex phenotype like obesity, hypertension, IFG, T2D and dyslipidemia in the two selected population groups [26]. Further, in the present study, significant differences were observed between the two tribal populations w.r.t the distribution of ACE I/D polymorphism where individuals with DD genotype were found to be significantly higher among Mizo population. Further, when the association was observed between IFG, T2D, dyslipidemia and ACE I/D polymorphism, there seems to be variability in the association. In the present study, DD genotype is found to be significantly associated with T2D among Mizo tribe. The present result, among Mizo tribe is in concordance with studies conducted by Vishwanathan et al.,2001, Bhavani et al.,2006 in South India and Raza et al,2013 in North India $[15,43]$ studies conducted on Japanese, Saudi Arabian, Egyptian population, $[14,38,39]$ where the association of DD genotype and T2D were reported. A large meta-analysis of 24 reports by Zhou et al., 2010 validated the association of D allele with Type 2 diabetes in Caucasian and East Asian populations [39]. No association between DD genotype and Type 2 diabetes among Liangmai tribe is in concordance with studies conducted by Chmaisse et al., 2009 in Lebanese population and Pirozzi et al., 2018 among Brazillain Type 2 patients [40,44]. Reporting the association between IFG/T2D and dyslipidemia condition, only high TC and high LDL are found to pose a significant risk for IFG and T2D only among Mizo tribe and not among Laingmai tribe. However, ACE I/D polymorphism is not found to be associated with any of the considered lipids variables in both the Liangmai and Mizo tribes. As per previous reports individuals with obesity, hypertension, and abnormal lipid variables, are significantly higher among Mizo tribe making this tribe prone to Cardiovascular diseases [26]. Further DD genotype which is also found to be associated with T2D is found to be more frequent in Mizo tribe, which indicates that major contributors of T2D in Mizo tribe could be possibly through ACE I/D polymorphism in light of other risk factors. However, obesity is not associate with IFG and T2D and hypertension is not found to be associated with IFG and T2D whereas dyslipidemia only in terms of high TC and high LDL are found to be associated with IFG and T2D.

D allele in combination with high TC and high LDL was found to pose more than 2-fold significant increased risk for IFG and T2D only in Mizo tribe. As the frequency of abnormal TC and abnormal LDL is very high in this population [26] with a very high frequency of DD genotype as $43.8 \%$, one can consider Mizo tribe to be at risk for IFG and T2D.

Further Liangmai Tribe inhabiting hilly terrain is expected to have high physical activity and so the effect of DD genotype in the causation of IFG and Type 2 diabetes is nullified which is not the case in case of Mizo tribe. The present study is an example of gene-environment interaction where DD genotype or D allele and dyslipidemia (high TC and high LDL) are posing risk for IFG and T2D both independently and in combination only among Mizo tribe with relatively less physical activity attributed to their residence in less hilly terrain. But no such association is found among the Laingmai tribe which resides in high hilly terrain

\section{Conclusion}

The present study shows a differential association of the major risk factors - obesity, hypertension, dyslipidemia, ACE I/D polymorphism with IFG and T2D among the two studied populations. The study indicates that individuals with DD genotype and dyslipidemia in Mizo population are prone to IFG and Type 2 diabetes, which makes this population an at-risk for future cardiovascular adversities.

\section{Declarations}

\section{Funding:}

The authors acknowledge the grants received from Research and Development Grant,

University of Delhi (2014-15).

\section{Conflicts of interest/ Competing interests}

All the authors declared that they have no conflict of interest.

\section{Availability of data and materials}

The data that supports the finding of this study are available from the corresponding author upon reasonable request.

\section{Code availability}


Not applicable

\section{Author's contributions:}

Conceptualization: KNS, NKD

Data curation: SR, SSN, VC, MKN

Formal Analysis: SR, SSN, VC, MKN

Funding Acquisition: NKD

Investigation: KNS, NKD

Methodology: KNS, NKD

Project Administration: NKD

Resources: KNS, NKD

Software: SR

Supervision: KNS, NKD

Validation: KNS, NKD, PRM

Visualization: KNS, NKD, PRM

Writing - Original Draft Preparation: SR, KNS

Writing - Review and Editing: SR, KNS, NKD, PRM

Ethics approval: The Ethical committee, Department of Anthropology, University of Delhi, India approved the study.

Consent to participate: The written informed consents were obtained from all the subject participants before conducting the study.

\section{Consent to publication: Not applicable}

Acknowledgement

The authors acknowledge the grants received from Research and Development Grant, University of Delhi (2014-15). The authors also acknowledge Department of Anthropology, Manipur University for granting permission to use laboratory facilities during fieldwork.

\section{References}

1. Wild S, Roglic G, Green A, Sicree R, King H (2004) Global prevalence of diabetes: estimates for the year 2000 and projections for 2030. Diabetes care. 27:1047-53. https://doi.org/10.2337/diacare.27.5.1047

2. Federation ID. IDF Diabetes Atlas 6th. htp://www. idf. 2015, [accessed 20-10-2017].

3. Zimmet PZ (2017) Diabetes and its drivers: the largest epidemic in human history?. Clin Diabetes Endocrinol 3:1. https://doi.org/10.1186/s40842-016-0039-3

4. Kumar A, Bhatia M, Goel PK, Jain RB (2016) Diabetes in Tribes of India: A literature review. Journal of Social Health and Diabetes. 4:041043. https://doi.org/10.4103/2321-0656.164795

5. Mohan V, Sandeep S, Deepa R, Shah B, Varghese C (2007) Epidemiology of type 2 diabetes: Indian scenario. Indian J. Med. Res 125:217-30 http://www.icmr.nic.in/ijmr/2007/march/0302.pdf

6. Upadhyay RP, Misra P, Chellaiyan VG, Das TK, Adhikary M, Chinnakali P, Yadav K, Sinha S (2013) Burden of diabetes mellitus and prediabetes in tribal population of India: a systematic review. Diabetes Res. Clin. Pract 102:1-7. https://doi.org/10.1016/j.diabres.2013.06.011

7. Lorber D (2014) Importance of cardiovascular disease risk management in patients with type 2 diabetes mellitus. Diabetes Metab Syndr Obes 7:169. https://dx.doi.org/10.2147\%2FDMSO.S61438 
8. Joshi SR, Anjana RM, Deepa M, Pradeepa R, Bhansali A, Dhandania VK, Joshi PP, Unnikrishnan R, Nirmal E, Subashini R, Madhu SV (2014) Prevalence of dyslipidemia in urban and rural India: the ICMR-INDIAB study. PloS one. 9:e96808.

https://doi.org/10.1371/journal.pone.0096808

9. Deepa M, Anjana RM, Mohan V (2017) Role of lifestyle factors in the epidemic of diabetes: lessons learnt from India. Eur J Clin Nutr 71:825. https://doi.org/10.1038/ejcn.2017.19

10. Costerousse, O., Danilov, S., \& Alhenc-Gelas, F. (1997) Genetics of angiotensin I-converting enzyme. Clin. Exp. Hypertens 19:659-669. https://doi.org/10.3109/10641969709083177

11. Carlsson PO, Berne C, Jansson L (1998) Angiotensin II and the endocrine pancreas: effects on islet blood flow and insulin secretion in rats. Diabetologia 41:127-33. https://doi.org/10.1007/s001250050880

12. Dhar S, Ray S, Dutta A, Sengupta B, Chakrabarti S (2012) Polymorphism of ACE gene as the genetic predisposition of coronary artery disease in Eastern India.Indian Heart J. 64:576-81. https://doi.org/10.1016/j.ihj.2012.08.005

13. Sayed-Tabatabaei FA, Oostra BA, Isaacs A, Van Duijn CM, \& Witteman JCM. (2006) ACE polymorphisms. Circ.Res 98:1123-1133 https://doi.org/10.1161/01.RES.0000223145.74217.e7

14. Daimon M, OIZUMI T, SAITOH T, KAMEDA W, HIRATA A, YAMAGUCHI H, OHNUMA H, IGARASHI M, TOMINAGA M, KATO T (2003) The D allele of the angiotensin-converting enzyme insertion/deletion (I/D) polymorphism is a risk factor for type 2 diabetes in a populationbased Japanese sample. Endocr. J 50:393-8. https://doi.org/10.1507/endocrj.50.393

15. Viswanathan V, Zhu Y, Bala K, Dunn S, Snehalatha C, Ramachandran A, Jayaraman M, Sharma K. Association between ACE gene polymorphism and diabetic nephropathy in South Indian patients. Jop. 2001 Mar 1,2(2):83-7.

16. Stephens JW, Dhamrait SS, Cooper JA, Acharya J, Miller GJ, Hurel SJ, Humphries SE (2005) The D allele of the ACE I/D common gene variant is associated with Type 2 diabetes mellitus in Caucasian subjects. Mol Genet Metab 84:83-9. https://doi.org/10.1016/j.ymgme.2004.09.002

17. Xi B, Ruiter R, Chen J, Pan H, Wang Y, Mi J. The ACE insertion/deletion polymorphism and its association with metabolic syndrome. Metabolism. 2012 Jun 1,61(6):891-7.

18. Choudhury I, Jothimalar R, \& Patra AK (2012) Angiotensin converting enzyme gene polymorphism and its association with hypertension in South Indian population. Indian Journal of Clinical Biochemistry, 27, 265-269. https://doi.org/10.1007/s12291-012-0217-8

19. Rana G, Yadav S, Joshi S, Saraswathy KN (2018) Association of DD genotype of angiotensin-converting enzyme gene (I/D) polymorphism with hypertension among a North Indian population. J Community Genet 9:51-5. https://doi.org/10.1007/s12687-0170321-9

20. Strazzullo P, lacone R, lacoviello L, Russo O, Barba G, Russo P, D'Orazio A, Barbato A, Cappuccio FP, Farinaro E, Siani A (2003) Genetic variation in the renin-angiotensin system and abdominal adiposity in men: the Olivetti Prospective Heart Study. Ann. Intern. Med. 138:17-23. https://doi.org/10.7326/0003-4819-138-1-200301070-00007

21. Vallejo M, Martinez-Palomino G, Ines-Real S, Perez-Hernandez N, Juarez-Rojas JG, \& Vargas-Alarcon, G (2009) Relationship between the angiotensin I-converting enzyme insertion/deletion (I/D) polymorphism and cardiovascular risk factors in healthy young Mexican women. Genet Test Mol Bioma 13:237-242 https://doi.org/10.1089/gtmb.2008.0105

22. Mukherjee SK (1998) Jewish movement in the hills of Manipur and Mizoram. Social Movements in the North-East India. New Delhi: Indus Publishing Company/NEICSSR, Shillong 189-98

23. Cordaux R, WeissG, Saha N, Stoneking M. (2004) The northeast Indian passageway: a barrier or corridor for human migrations? Mol. Biol. Evol., 21, 1525-1533. https://doi.org/10.1093/molbev/msh151

24. Ningombam SS, Chhungi V, Newmei MK, Rajkumari S, Devi NK, Mondal PR, Saraswathy KN (2018) Differential distribution and association of FTO rs9939609 gene polymorphism with obesity: a cross-sectional study among two tribal populations of India with East-Asian ancestry. Gene 647:198-204. https://doi.org/10.1016/j.gene.2018.01.009

25. Ningombam SS, Rajkumari S, Chhungi V, Newmei MK, Devi NK, Mondal PR, Saraswathy KN (2019) Type 2 diabetes and FTO rs9939609 gene polymorphism: a study among the two tribal population groups of Manipur, North East India. INT J DIABETES DEV C $39: 60-5$. https://doi.org/10.1007/s13410-018-0634-1

26. Chhungi V, Ningombam SS, Yadav S, Singh HS, Devi NK, Chandel S, Mondal PR, Sachdeva MP, Saraswathy KN (2019) Prevalence of cardiovascular risk factors among tribal and non-tribal populations with East Asian Ancestry from North East India. Am J Hum Biol e23263. https://doi.org/10.1002/ajhb.23263

27. Chobanian AV, Bakris GL, Black HR, Cushman WC, Green LA, Izzo Jr JL, Jones DW, Materson BJ, Oparil S, Wright Jr JT, Roccella EJ (2003) The seventh report of the joint national committee on prevention, detection, evaluation, and treatment of high blood pressure: the JNC 7 report. Jama. 289:2560-2571. doi:10.1001/jama.289.19.2560

Page 6/10 
28. Rigat B, Hubert C, Alhenc-Gelas F, Cambien F, Corvol P, Soubrier F (1990) An insertion/deletion polymorphism in the angiotensin Iconverting enzyme gene accounting for half the variance of serum enzyme levels. J. Clin. Invest 86:1343-6. https://doi.org/10.1172/JCl114844

29. MWer S, Dykes D, Polesky H. A simple salting out procedure for extracting DNA from human nucleated cells. Nucleic acids res. 1988,16(3):1215.

30. Hsieh MC, Lin SR, Hsieh TJ, Hsu CH, Chen HC, Shin SJ, Tsai JH (2000) Increased frequency of angiotensin-converting enzyme DD genotype in patients with type 2 diabetes in Taiwan. Nephrol. Dial. Transplant. 15:1008-13. https://doi.org/10.1093/ndt/15.7.1008

31. Degirmenci I, Kebapci N, Basaran A, Efe B, Gunes HV, Akalin A, Kurt H, Urhan M, Demirustu C (2005) Frequency of angiotensin-converting enzyme gene polymorphism in Turkish type 2 diabetic patients. Int J Clin Pract Suppl 59:1137-42. https://doi.org/10.1111/j.13685031.2005.00586.x

32. Singh PP, Naz I, Gilmour A, Singh M, Mastana S. Association of APOE (Hha1) and ACE (I/D) gene polymorphisms with type 2 diabetes mellitus in North West India. Diabetes research and clinical practice. 2006 Oct 1,74(1):95-102. https://doi.org/10.1016/j.diabres.2006.03.013

33. Habibullah M, Akter F, Qin X, Lohani M, Aldughaim MS, Al-Kaabi Y. Association between Angiotensin-Converting EnzymeInsertion/Deletion Polymorphism and Diabetes Mellitus-2 in Saudi Population. Asian Pacific Journal of Cancer Prevention: APJCP. 2021 Jan,22(1):119. https://doi.org/10.31557/apjcp.2021.22.1.119

34. Jayapalan JJ, Muniandy S, Chan SP (2010) Null association between ACE gene I/D polymorphism and diabetic nephropathy among multiethnic Malaysian subjects. Indian J Phys Anthropol Hum Genet 16:78. https://dx.doi.org/10.4103\%2F0971-6866.69351

35. Thomas GN, Tomlinson B, Chan JC, Sanderson JE, Cockram CS, Critchley JA (2001) Renin-angiotensin system gene polymorphisms, blood pressure, dyslipidemia, and diabetes in Hong Kong Chinese: a significant association of the ACE insertion/deletion polymorphism with type 2 diabetes. Diabetes care. 24:356-61. https://doi.org/10.2337/diacare.24.2.356

36. Sikdar M, Purkait P, Raychoudhury P, Bhattacharya SK, Naidu JM, Sarkar BN. ACE gene insertion/deletion polymorphism and type-2 diabetic nephropathy in Eastern Indian population. Human Biology Review. 2013,2(1):66-76.

37. Barghash A, Al-Gharabli SI, Jweihan M, Tanbouz M, AlBarahmieh E, Hamad E, Al-Rifai N, AlHawari H, Tahtamouni LH. Angiotensin Converting Enzyme (ACE) Gene Polymorphism in Jordanian Type-1 and Type-2 Diabetic Patients. Jordan Journal of Biological Sciences. 2020 Apr 1,13(2).

38. Al-Saikhan Fl, Abd-Elaziz MA, Ashour RH (2017) Association between risk of type 2 diabetes mellitus and angiotensin-converting enzyme insertion/deletion gene polymorphisms in a Saudi Arabian population. Biomed Rep 7(1):56-60. https://doi.org/10.3892/br.2017.920

39. Zhou JB, Yang JK, Lu JK, An YH (2010) Angiotensin-converting enzyme gene polymorphism is associated with type 2 diabetes: a metaanalysis. Mol Biol Rep 37:67-73. https://doi.org/10.1007/s11033-009-9648-6

40. Chmaisse HN, Jammal M, Fakhoury H, Fakhoury R (2009) A study on the association between angiotensin-I converting enzyme I/D dimorphism and type-2 diabetes mellitus. Saudi J Kidney Dis Transpl 20:1038.

41. Gambano G, Anglani F, D'Angelo A (2000) Association studies of genetic polymorphisms and complex disease. The Lancet. 355(9200):308-11. https://doi.org/10.1016/S0140-6736(99)07202-5

42. Settin A, El-Baz R, Ismaeel A, Tolba W, Allah WA (2015) Association of ACE and MTHFR genetic polymorphisms with type 2 diabetes mellitus: susceptibility and complications. J Renin-Aldos-Aldo s 16:838-843. https://doi.org/10.1177\%2F1470320313516172

43. Bhavani BA, Padma T, Sastry BK, Reddy NK, Nausheen K (2005) The insertion I/deletion D polymorphism of angiotensin-converting enzyme (ACE) gene increase the susceptibility to hypertension and/or diabetes. Int J Hum Genet 5:247-52 https://doi.org/10.1080/09723757.2005.11885934

44. Pirozzi FF, Belini Junior E, Okumura JV, Salvarani M, Bonini-Domingos CR, Ruiz MA (2018) The relationship between of ACE I/D and the MTHFR C677T polymorphisms in the pathophysiology of type 2 diabetes mellitus in a population of Brazilian obese patients. Arch Endocrinol Metab 62:21-6. http://dx.doi.org/10.20945/2359-3997000000005

\section{Tables}

Table 1. Distribution of ACE I/D rs4646994 polymorphism with Impaired blood glucose (IFG) and Type 2 diabetes among Liangmai and Mizo population of Manipur. 


\begin{tabular}{|c|c|c|c|c|c|c|c|c|c|c|c|c|c|}
\hline \multirow{4}{*}{$\begin{array}{l}\text { Geno- } \\
\text { type }\end{array}$} & \multicolumn{6}{|l|}{ Liangmai } & \multicolumn{7}{|l|}{ Mizo } \\
\hline & & Normal & IFG & (a) $x^{2}$ & T2D & (b) $\times 2$ & & Normal & IFG & (a) $x^{2}$ & T2D & (b) $x^{2}$ & \\
\hline & Total & $\mathrm{N}(\%)$ & $N(\%)$ & value & $\mathrm{N}(\%)$ & & Total & $N(\%)$ & $N(\%)$ & value & $\mathrm{N}(\%)$ & $p-$ & (c) $\times 2$ \\
\hline & $\mathrm{N}(\%)$ & & & & & value & N (\%) & & & & & & $\begin{array}{l}\mathrm{p}- \\
\text { value }\end{array}$ \\
\hline \multirow[t]{2}{*}{ II } & 72 & 66 & 2 & $0.6^{\#}$ & 4 & $0.9^{\#}$ & 114 & 71 & 12 & 0.9 & 31 & 0.05 & \\
\hline & $(21.20)$ & (21.7) & (11.1) & & $(23.50)$ & & $(42.1)$ & $(44.90)$ & $(42.9)$ & & (36.9) & & \\
\hline \multirow[t]{2}{*}{ ID } & 179 & 157 & 12 & & 10 & & 95 & 58 & 11 & & 26 & & $<0.001$ \\
\hline & $(52.8)$ & $(51.6)$ & $(66.7)$ & & $(58.80)$ & & (35.2) & $(36.70)$ & (39.3) & & (31) & & \\
\hline \multirow[t]{2}{*}{$\mathrm{DD}$} & 88 & 81 & 4 & & 3 & & 61 & 29 & 5 & & 27 & & \\
\hline & (26) & $(26.6)$ & (22.2) & & $(17.60)$ & & (22.6) & (18.40) & (17.9) & & (32.1) & & \\
\hline
\end{tabular}

${ }^{(a)} \chi 2$ ( $p$-value) between Normoglycemia and IFG; (b) $\chi 2$ ( $p$-value) between Normoglycemia and T2D; (c) X2 ( $\mathrm{p}$-value) between the distribution of ACE I/D polymorphism between Liangmai and Mizo tribe. ${ }^{\#}$ Yates's corrected; ${ }^{*} \mathrm{p}-$ Value $<0.05$ significant.

Table 2. Odds ratio (OR) analysis of ACE I/D rs4646994 polymorphism with IFG and Type 2 diabetes.

\begin{tabular}{|lll|}
\hline Model & Liangmai & Mizo \\
\hline Dominant (II/ID+DD) & OR $(95 \% \mathrm{Cl}) \mathrm{p}$ value & OR $(95 \% \mathrm{Cl}) \mathrm{p}$ value \\
\hline N vs IFG & $2.21(0.49-9.89) 0.29$ & $1.08(0.48-2.45) 0.83$ \\
\hline N vs T2D\# & $0.94(0.29-3.02) 0.91$ & $1.43(0.82-2.49) 0.20$ \\
\hline Co-dominant (II/DD) & & \\
\hline N vs IFG & $1.63(0.28-9.17) 0.58$ & $1.02(0.33-3.15) 0.97$ \\
\hline N vs T2D\# & $0.65(0.14-3.04) 0.58$ & $2.10(1.10-4.39) 0.02^{*}$ \\
\hline Co-dominant (II/ID) & & \\
\hline N vs IFG & $2.52(0.54-11.58) 0.23$ & $1.2(0.46-2.75) 0.79$ \\
\hline N vs T2D\# & $1.07(0.32-3.58) 0.90$ & $1.04(0.55-1.97) 0.89$ \\
\hline Recessive (II+ID/DD) & & \\
\hline N vs IFG & $0.78(0.25-2.45) 0.68$ & $0.96(0.33-2.75) 0.95$ \\
\hline N vs T2D\# & $0.64(0.17-2.32) 0.48$ & $\mathbf{2 . 1 8}(1.16-4.09) 0.01 *$ \\
\hline \# Age adjusted ; ${ }^{*} p-V a l u e<0.05$ significant. & \\
\hline
\end{tabular}

Table 3. Gene (ACE I/D)-environment (Dyslipidemia and Hypertension) interactions in IFG AND T2D. 


\begin{tabular}{|c|c|c|c|c|}
\hline \multirow[t]{5}{*}{ Variables } & \multicolumn{2}{|l|}{ Liangmai } & \multicolumn{2}{|l|}{ Mizo } \\
\hline & $N$ vs IFG & $\mathrm{N}$ vs T2D\# & $N$ vs IFG & $\mathrm{N}$ vs T2D\# \\
\hline & ACE I/D & ACE I/D & ACE I/D & ACE I/D \\
\hline & (II vs ID+DD) & (II vs ID+DD) & (II vs ID+DD) & (II vs ID+DD) \\
\hline & OR $(95 \% \mathrm{Cl}) \mathrm{p}$ value & OR $(95 \% \mathrm{Cl}) \mathrm{p}$ value & OR $(95 \% \mathrm{Cl}) \mathrm{p}$ value & OR $(95 \% \mathrm{Cl}) \mathrm{p}$ value \\
\hline TC & $1.72(0.64-4.5) 0.2$ & $1.35(0.46-3.82) 0.52$ & $2.51(1.10-5.68)<0.005^{\star}$ & $2.56(1.45-4.53)<0.005^{\star}$ \\
\hline TG & $0.99(0.34-2.86) 0.9$ & $2.29(0.85-6.13) 0.09$ & $1.22(0.49-2.99) 0.66$ & $1.01(0.99-1.02) 0.06$ \\
\hline HDL & $1.19(0.45-3.10) 0.71$ & $0.81(0.29-2.25) 0.69$ & $0.55(0.15-1.97) 0.36$ & $0.77(0.31-1.61) 0.49$ \\
\hline LDL & 1.38 (0.47-4.03) 0.5 & $0.77(0.21-2.76) 0.69$ & $2.36(1.03-5.44) 0.04^{*}$ & $2.48(1.41-4.37)<0.005^{\star}$ \\
\hline VLDL & $0.91(0.34-2.86) 0.98$ & $2.29(0.85-6.13) 0.09$ & $1.22(0.49-2.99) 0.66$ & $1.36(0.76-2.46) 0.29$ \\
\hline HTN & $1.06(0.43-2.76) 0.89$ & $1.22(0.43-3.16) 0.81$ & $1.07(0.46-2.47) 0.86$ & $1.3(0.73-2.28) 0.36$ \\
\hline \multicolumn{5}{|c|}{${ }^{\#}$ Age adjusted: Age ; ${ }^{*} \mathrm{p}$-value $<0.05$ significant. } \\
\hline \multicolumn{5}{|c|}{$\begin{array}{l}\text { Data represented as TC: Total Cholesterol; TG: Triglyceride; HDL: High-density lipoprotein; LDL: Low-density lipoprotein; VLDL: Very low- } \\
\text { density lipoprotein; HTN: Hypertension. }\end{array}$} \\
\hline
\end{tabular}

\section{Figures}

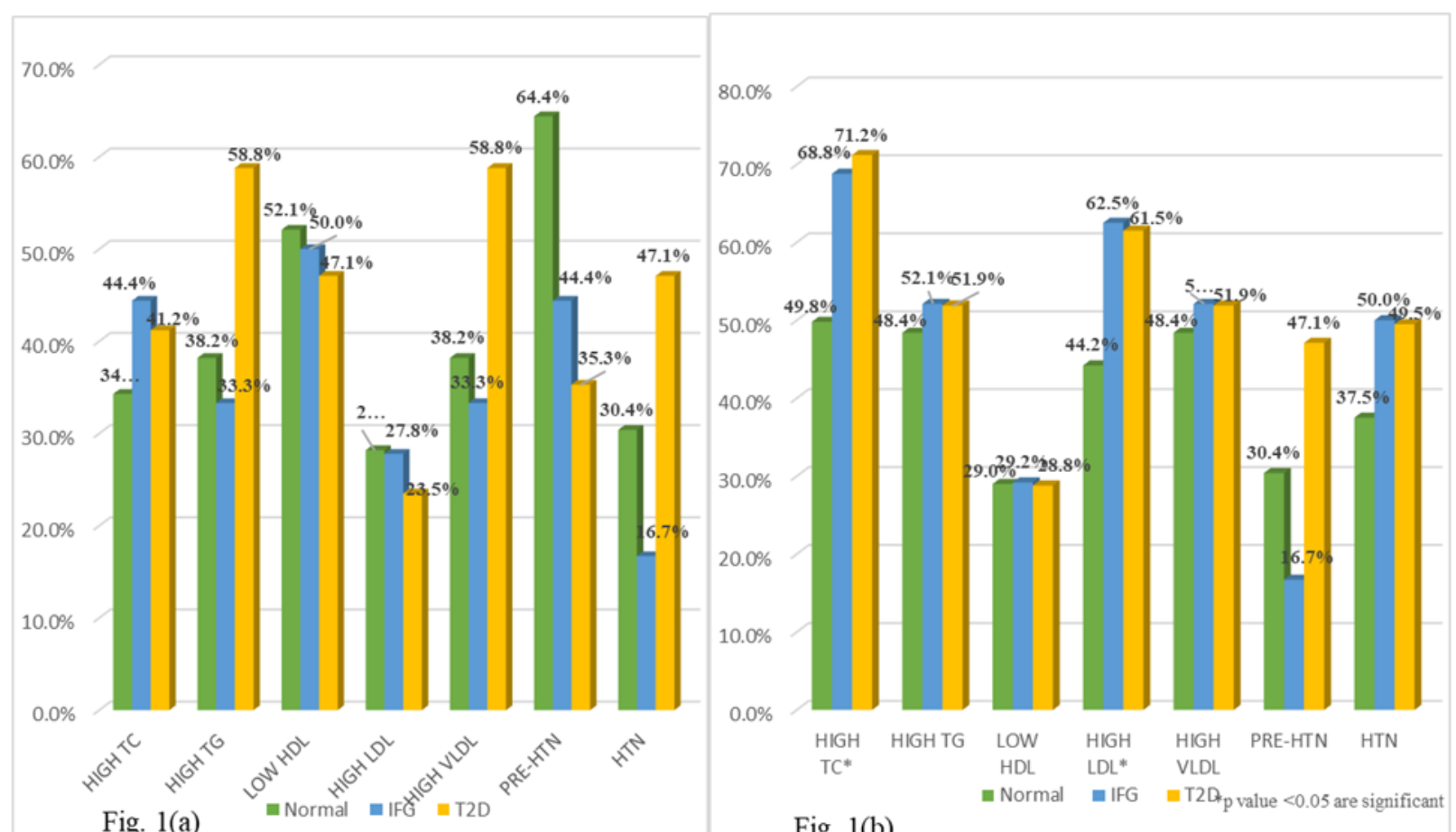

Data represented as TC: Total Cholesterol; TG: Triglyceride; HDL: High-density lipoprotein; LDL: Low-density lipoprotein; VLDL: Very low-density lipoprotein; HTN: Hypertension.

\section{Figure 1}

Distribution of dyslipidemia and hypertension among individuals with normoglycemia, IFG and T2D among Liangmai tribe [1(a)] and Mizo tribe [1(b)] of Manipur. 

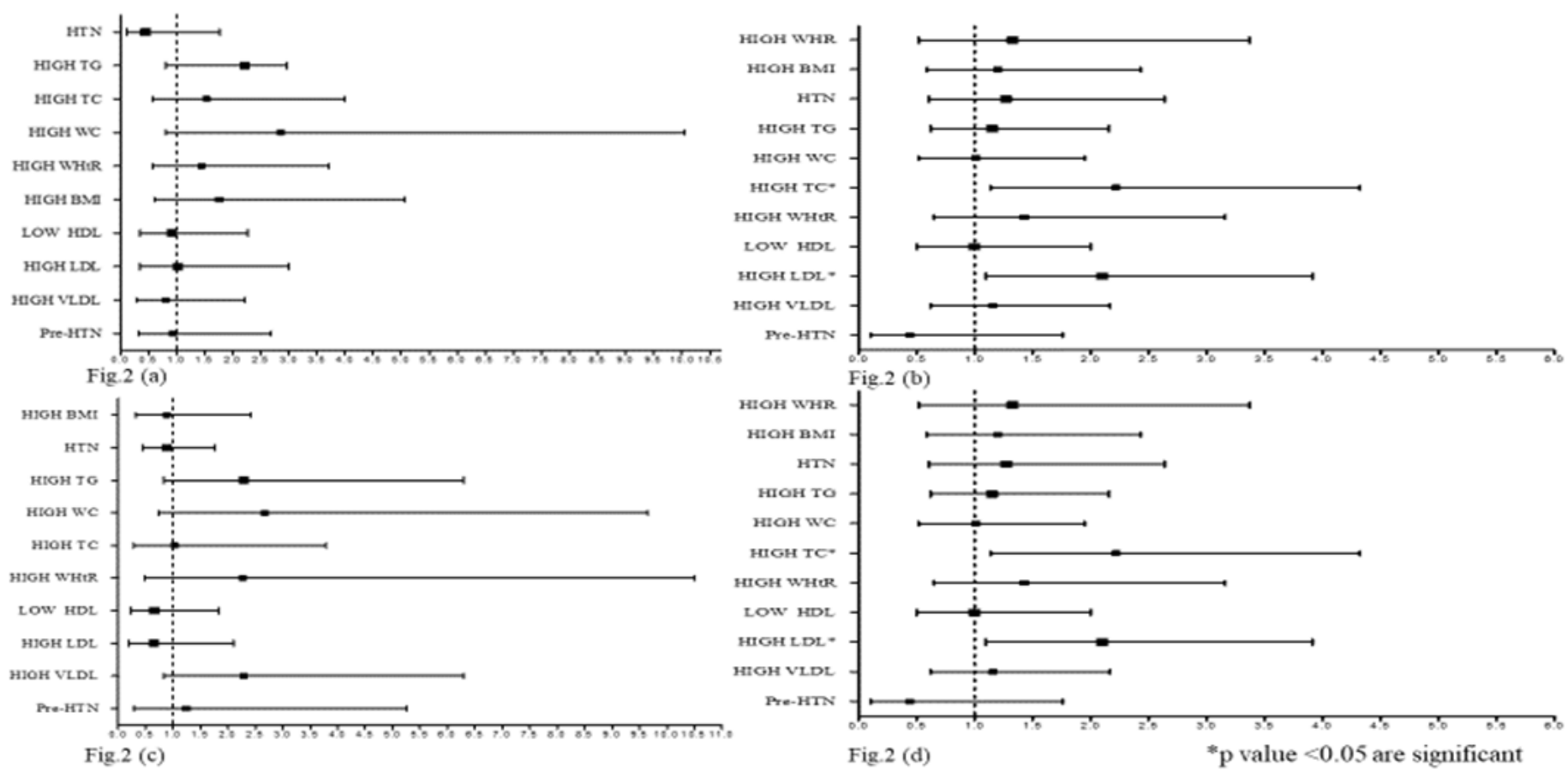

Data represented as TC: Total Cholesterol; TG: Triglyceride; HDL: High-density lipoprotein; LDL: Low-density lipoprotein; VLDL: Very low-density lipoprotein; HTN: Hypertension.

Figure 2

Logistic regression analysis of IFG with lipid variables, obesity variants, and blood pressure among Liangmia tribe [2(a)] and Mizo tribe [2 (b)], logistic regression analysis of T2D with lipid variables, obesity variants, and blood pressure among Liangmia tribe [2(c)] and Mizo tribe [2(d)].

\section{Supplementary Files}

This is a list of supplementary files associated with this preprint. Click to download.

- SupplementaryTable1.docx 